Uniwersytet Rzeszowski, Wydział Prawa i Administracji,

Pracownia Kryminologii i Kryminalistyki

DOI: $10.13166 / J M S / 106050$

JOURNAL OF MODERN

dsemkow@ur.edu.pl

SCIENCE TOM 1/40/2019,

\title{
NEW PSYCHOACTIVE SUBSTANCES. THE PHENOMENON DEVELOPMENT AND THE INSTITUTIONAL AND LEGAL MECHANISMS FOR ITS PREVENTION
}

\begin{abstract}
The phenomenon observed in many countries for many years is an attempt to bypass the law by launching psychoactive substances on the market whose possession and sale is not regulated by the existing drug law. The number of chemically and biologically modified substances is dramatically increasing and the substances themselves are increasingly stronger and threatening people's health and lives. Issues relating to the occurrence of New Psychoactive Substances (NPS) are the subject of increasingly in-depth analyses. In connection with the steadily increasing number of NPS and their substantial availability, there are more and more doubts about the effectiveness of the model adopted in earlier years in Europe and in individual countries, whose purpose is to subject new psychoactive substances to legal control. Based on the information presented in the article, one can assume that the reason for the development of new psychoactive substances to date was, on the one hand, the weakness of the legal regulations in force, both national and international, and on the other, specialized technical and chemical capabilities of manufacturers. Another thesis that can be put in the context of the studied subject is the statement that the phenomenon of new psychoactive substances has a high criminogenic susceptibility and is a decisively negative phenomenon, classified as the pathology of social life. In view of the above, the activities of prevention, detection and control of new psychoactive substances are important in the process of effective fight against NPS.

The article does not constitute a comprehensive and complex overview of what NPS are. The aim of the study is a multifaceted analysis of the phenomenon of such
\end{abstract}


substances, which will allow for a deeper understanding of the causes of such a wide scale of NPS, their diversity and ease of accessibility. Considering the above, the article attempts to stress the priority issues according to the article's author and which are crucial in the process of universally understood NPS prevention - i.e. international cooperation, national legal regulations, and chemical analyses conducted in forensic laboratories.

KEYWORDS: new psychoactive substances, new drugs, smart, legal highs / herbal highs / boosters, prevention, legal regulations, criminogenic factors

\section{INTRODUCTION}

The issue of new psychoactive substances is an interdisciplinary problem and is interesting for representatives of various circles, including the judiciary, law enforcement agencies, health care, education, and social welfare.

Regardless of whether and what kind of legal control covers the substances in question, they can undoubtedly be classified as negative phenomena from the sphere of social life and public health. Such phenomena do not have to be prohibited by law, but they either have a high criminogenic load or they are structurally similar to crime (Hanausek, 2009, p. 47).

An attempt to define psychoactive substances unambiguously poses many difficulties. There are two reasons for this basic problem. The first one is the fact that the list of the mentioned substances is rapidly expanding and changing. The second difficulty is a subtle difference in defining between psychoactive and supportive. It is also important to note that in the definition of addiction proposed by the World Health Organization (WHO 1969) the word "Drug" was equivalent to the concept of a "psychoactive substance" (Jędrzejko, Kowalewska, 2009, p. 29). As stressed by K. Zajączkowski, this term caused many misunderstandings, which was because the term "drug" is most often associated with a process of medical treatment. The use of psychoactive substances in order to enter a state of intoxication cannot be treated as a treatment process. A similar misunderstanding occurred in the case of definitions of addiction as a disease. In fact, several diagnostic terms were used interchangeably, such as: drug addiction, drug dependence, pharmacomania, addiction, chemical dependency, abuse, etc. (Zajączkowski, 2003, p. 7). Terminological problems were resolved in 1992 
by entering another version of mental illnesses and behaviour disorders into the International Classification of Diseases (ICD-10) in 1992, by using the following terms: psychoactive substance, harmful use, dependence syndrome. The CD-10 classified ten groups of psychoactive substances, guided by the use universality of individual substances and clinical symptoms induced by them(Zajączkowski, 2003, p.7). In order to detail the current ICD-10 classification, it is necessary to point to psychological and behavioural disorders caused by: drinking alcohol; using opiates; using cannanibola; using hypnotics and sedatives; using cocaine; using other psychostimulants; using hallucinogenic substances; smoking tobacco; using volatile solvents; using several substances or using other psychoactive substances. K. Zajączkowski stresses the substantive justification for the above division, which for the most part results from the fact that persons using psychoactive substances are not guided in their selection by a pharmacological mechanism of their effect or a chemical structure of a compound, but by the acquired knowledge about their overall impact on the human mental sphere. Guided by this theory, the author simplified the ICD-10 classification by dividing substances into three main groups: narcotic and sedative drugs; stimulants; hallucinogenic substances (Zajączkowski, 2003, p. 9). Having regard to the existing division, it should be pointed out that the psychoactive substance was defined as a substance that, when taken in, affects mental processes, e.g. cognitive processes, or a mood. T. Woronowicz, defines psychoactive substances as chemicals that by their effect on the human body modify a person's mood and change (falsify) his/her perception of the surrounding reality. The author also emphasizes the relationship between taking these substances and the possibility of becoming addicted. The list of psychoactive substances, in addition to alcohol, contains, among others, poppy derivatives, various stimulants such as amphetamine, cocaine, caffeine; medicines; volatile solvents; tobacco (Woronowicz, 2003, p. 163).

Another definition states that psychoactive substances are those that change awareness, influence the human central nervous system, affect thinking, emotions, sleep, appetite, sexual sphere, social relations, and other aspects of human functioning. These substances cause the suppression of emotions, mood changes, perception distortion of the surrounding reality 
and of oneself. Under the influence of psychoactive substances, the person taking them experiences pleasant and intense emotions, gets rid of troubles and worries, overcomes inhibitions and scruples, raises his/her self-esteem, etc. It should be emphasized strongly that the changes in well-being in this way are temporary, because psychoactive substances are characterized by an important feature that is their short-term effect (Zajączkowski, 2003, p. 7). In accordance with the conventions of the United Nations Organization signed by Poland: The UN Uniform Convention on Narcotic Drugs of 1961 (Journal of Laws of 1966, No. 45, item 277, as amended) together with the additional protocol of 1972 (Journal of Laws of 1996, No. 35, item 149) and the Convention on Psychotropic Substances of 1976, most of these substances are subject to control consisting in allowing only for production of medicines used in medical treatment, supervision over their turnover and prohibition of transport across the border (of course, this does not apply to caffeine, tobacco and alcohol) (Woronowicz, 2003, p. 163).

\section{NEW PSYCHOACTIVE SUBSTANCES. TERMINOLOGICAL ISSUES AND CLASSIFICATION}

The emergence of new psychoactive substances that are not controlled under the current drug law is not a new phenomenon. In recent years, different definitions and terms have been used for new psychoactive substances that appear on the market and are not subject to international control. The use of different terms in order to define the same substance may cause chaos and lack of coherence. Now the preferred term isNew Psychoactive Substances, hereinafter referred to as NPS (Farre, Galindo, Torrens, 2014, p. 581).

Substances such as heroin, cocaine, marijuana, their derivatives, and precursors, along with several amphetamines, barbiturates, benzodiazepines, and other narcotic drugs, are controlled under the UN Conventions mentioned above. Any psychoactive substances which are not included in the lists and which are not subject to control as the above-mentioned substances are defined as new psychoactive substances, regardless of how long they have been known and used. The adoption of the NPS definition at the level of international legislation made it possible to standardize the subject of nomenclature used by lawyers, scientists, and researchers (New psychoactive 
substances - chemists vs. lawyers). It is worth noting that the European Monitoring Centre for Drugs and Drug Addiction (EMCDDA) also uses the definition cited above to include in the NSP group the substances that are not listed in the above-mentioned UN Conventions, and which may pose comparable (with the drugs mentioned in the conventions) threats to public health.

The effect of NPS on the body, including in particular the Central Nervous System, is often similar to the action of controlled psychoactive substances. Therefore, it seems reasonable to claim that the effect of new psychoactive substances refers to the action of traditional drugs, because they imitate the action of marijuana, stimulate like cocaine or amphetamine, have an empathogenic effects like ecstasy, or have hallucinogenic effects like LSD.

The frequently accepted division of new psychoactive substances classifies them into the following groups: the first includes synthetic cannabinoids; the second group is formed by cathinones and cathinone derivatives that have similar effects to amphetamine - agitation, euphoria, irritation or a sense of calm, insomnia, fear states; the next group includes phenethylamines and their derivatives which have psychedelic and hallucinogenic effects, and cause changes in consciousness; the fourth group consists of so-called tryptamines and their derivatives - they cause the reception distortion of external stimuli and have hallucinogenic effects; piperazines and derivatives (including benzylpiperazine listed as a prohibited substance in Poland in 2009), which are the main ingredient of boosters; the last group, including "others" is very wide, not only in terms of the type of substances, but also the effects that they induce (Tkaczyk-Rymanowska, 2016, pp. 135-136).

The Polish National Medicines Institute, and more specifically the National Laboratory for Control of Medicinal Products,Medicinal Devices and Biocidal Products, based on the clinical effects caused by new psychoactive substances, categorized these substances into the following 10 groups: 1) stimulants - psychostimulants - stimulants of the CNS, including phenylethylamine and cathinones; 2) depressants - substances that retard the CNS, e.g. opioids, benzodiazepine derivatives, alcohol; 3) psychedelics - psychodysleptics - substances that cause disorders in the CNS; 4) trypamine derivatives; 5) psychedelic amphetamines; 6) dissociators; 7) delirants; 8) 
mescaline derivatives; 9) lizergamides; 10) cannabinoids - a group of compounds that combine stimulating, depressive and psychedelic effects (depending on the dose) (New psychoactive substances, so-called boosters, 2017).

The most known examples of NPS include substances such as synthetic cannabinoids contained in different herbal blends, piperazines, products sold as "bath salts" (i.e. substances such as mephedrone) and different phenethylamines. Ketamine was one of the first NPS. The first abuse instances of this substance were at the beginning of the 1980s in North America. In Europe, the use of those substances became a noticeable phenomenon in the 1990s. Then it spread to Asia, to a lesser extent to South America and South Africa. New psychoactive substances belonging to the group of phenethylamines appeared on the market in the 1990s, and substances belonging to the piperazine family at the beginning of the first decade of the 21 st century. The year 2004 dated as the beginning of synthetic cannaniboids such as Spice. The next emerging NPS group were cathinones and other newly emerging psychoactive substances (Farre, Galindo, Torrens, 2014 , p. 585). The popularity of Spice and analogous herb blends reached the highest value in the second half of 2008. Following reports on NPS on German television and press, these products were sold out and available only on the Internet. These herbs were sold in many countries of Western Europe. Even though these blends have been sold as incense, with the caveat "not for human consumption", they have been consumed as herbal drugs through smoking, similarly to cannabis. Consumers using these substances have pointed to the effects of their smoking similar to smoking cannabis. It should be emphasized, however, that the initial chemical and botanical analysis did not reveal the presence of cannabis in the blends. The list of ingredients included the mixture of other various plant ingredients. Because of the use of the indicated substances, their users have described a wide range of narcotic effects. However, they have not been covered by an analysis and clinical records. Despite the suspicion that the added synthetic compounds or plant extracts are the real source of the described narcotic pharmacological effects, these products were not banned by the authorities at that time. Because ofthe social discussion, the popularity of these substances as "legal drugs" grew rapidly, based on the opinion of them as "legal" alternatives to strictly 
regulated drugs such as, for example, marijuana. This is evidenced by the fact that at the end of 2008, on the German market there were at least eight products available with similar effectiveness and financial competitiveness (Lindigkeit, Boeheme, Eiserloh et al., 2009, p.58).

Newly established names: smart, legal highs, herbal highs, boosters (Warecki, 2010, p. 5), have been used as a collective concept for new psychoactive substances or products containing them that are not regulated by law, which in their effects are supposed to imitate the action and effects of drugs controlled by law. This term covers a wide range of synthetic and/or plant-based substances. In the international nomenclature, they are referred to as "legal highs", "herbal highs", "research chemicals", "party pills" (Farre, Galindo, Torrens, 2014, p. 581). It is to be noted that the term "boosters" is used only as a common name. It is not a legal definition, both under the national and international laws.

Based on the analysis of the collected material, one should point to the dispute existing in the professional literature regarding the applied nomenclature. In the opinion of some experts, the name "booster", although commonly used is incorrect. This results from the combination of two reasons. First of all, in the opinion of the opponents of this term use, by applying it, we treat substances contained in it, which in fact are drugs, as a separate type of stimulants. This is a mistake, because the only thing that distinguishes them from law-controlled drugs is that people have been using them for a short time. Secondly, the meaning of the word "booster" suggests that we are dealing with something stimulating. While only a part of these substances are stimulants. New drugs, as previously highlighted, are divided into separate groups depending on the way in which they work (Michalewski, Grabowski, Wodowski, 2015, p.3).

New drugs are most commonly sold via the Internet or in the so-called "smart shops". In most cases, they are marked intentionally erroneously in the context of their intended use. This means that they are marked as "not intended for human consumption", "bath salts", "incense sticks", "room fresheners", "plant food". This "legal market" can be distinguished from other drug markets by the speed with which suppliers bypass drug control, offering new alternatives to products controlled by law (Deluca, Davey, Corazza et al., 2012, pp. 221-226). 


\section{THE SITUATION ON THE MARKET OF NEW PSYCHOACTIVE SUBSTANCES, THEIR DISSEMINATION, AND THE EFFECTS OF THEIR USE}

In recent years, the use of NPS has become a truly global phenomenon. These substances have been used by the inhabitants of Europe, North America, Oceania, Asia, South America, and many African countries. In the sources and professional literature, new psychoactive substances are sometimes referred to as a phenomenon assigned to European countries and North America. It should be pointed out that UK residents represent $23 \%$ of the total number of recipients (users) of new psychoactive substances (Abdulrahim, BowdenJones, 2015, p. 10).It is considered that most new psychoactive substances are produced in Asia, in particular in China and India (United Nations Office, 2013, p.52). It is worth noting that China plays a special role in the increased availability of new psychoactive substances. In the case of this country, the clear majority of legal and operating chemical and pharmaceutical companies are responsible for the production of NPS (Morris, 2012). These companies produce many legal substitutes for controlled medicines - cannabinoids, stimulants, opioids, benzodiazepines - and then they send them quickly and cheaply to Europe and other countries. There, these substances become "legal boosters", "research chemicals" or "dietary supplements" which are sold openly in the streets and on the Internet. They are also sold on the illegal drug market under their own name or under the name of illegal drugs such as ecstasy, heroin, or cocaine. An increasing problem is the number of counterfeit medicines containing new substances, most often counterfeit tablets sold as diazepam and alprazolam (Ewans-Brown, Sedevor, 2017, p. 36). The next places in the NPS production process are occupied by Europe (The Czech Republic, Hungary, The Netherlands, Portugal, Spain, Ukraine, and the United Kingdom), both Americas, Africa, and Oceania [United Nations Office on Drugs and Crime (UNODC), The Challenge of, 2013].

Analysing the number of the detected new psychoactive substances, one should state that the concerns of experts have been confirmed, who, while emphasizing very numerous possibilities of changing the structure of chemicals, pointed to the fact that the number of manufactured substances would increase. 
This is indicated by the statistical data on the use of new psychoactive substances. It appears that in relation to psychoactive substances controlled by law, the use of new uncontrolled psychoactive substances has significantly increased in the last decade.The production and introduction of such substances is a promise of high profits without the risk of fines for their producers and substance traders. Once controlled in one country, the production and/or distribution centres of these substances are transferred to another country, so that sales, often carried out via the Internet, can be continued. Another way to avoid legal sanctions is to modify slightly their composition in such a way that they are not covered by the legislation of a given country (Farre, Galindo, Torrens, 2014, p. 585).

The European Monitoring Centre for Drugs and Drug Addiction (EMCDDA) monitors over 600 new substances through the EU Early Warning System (EWS). Most of them have been detected in the last 5 years. Considering how the trends in the society's demand for psychoactive substances are changing, it is true that it is not possible to say what the use of NPS will look like. However, it is noted that suppliers do not look for the next marijuana, heroin, or diazepam; they simply create substances that can mimic their effects and be produced, transported, and sold freely (EwansBrown, 2017, pp. 36-37).

The number of NPS reported by the Member States to the United Nations Office on Drugs and Crime (UNODC) rose from 166 at the end of 2009 to 251 in the mid 2012. This exceeded the total number of psychoactive substances controlled by international drug conventions, i.e. a total of 234 substances (World Drug Report 2013, 2013, p. 59).

The data provided by the European Monitoring Centre for Drugs and Drug Addiction show that in 2016 in Europe 66 new psychoactive substances were detected (European Drug Report. Trends and Developments, 2017, p. 33). The analysis of statistics from previous years allows to conclude that this figure is smaller than in the previous two years but is comparable to those recorded in 2012 and 2013.

The reasons for the decrease in the NPS detection scale have not been clearly specified. However, they may result from measures taken by European governments to ban the marketing of new substances, in particular their open 
sale as "boosters". An equally important aspect in detecting and combating the NPS market may be control measures and the operation of law enforcement agencies in China, directed against laboratories producing new substances (European Drug Report. Trends and Developments, 2017, p. 33).

Therefore, it should be said that the occurrence phenomenon of new psychoactive substances, despite the implemented methods of response, continues to be a significant challenge both for the governments of particular countries, as well as for international structures. Even though in 2016, one report of a new drug was submitted to the EU Early Warning System weekly, while the total number of newly detected substances was lower than in the previous years, it should be stressed that there is no convincing research on reducing the general availability of new psychoactive substances. In addition, even if the pace of new substances emergence is decreasing, the overall number of substances available on the market is still increasing. It is important that certain classes of NPS, in particular synthetic cathinones and cannabinoids, have consolidated their position on the drug market (European Drug Report. Trends and Developments, 2017, p. 16). The professional literature stresses that several current epidemiological indicators are poorly adapted or configured to watch new substances. This reflects the complexity and very dynamic nature of the market, including the fact that many users do not know what substances they use. These restrictions hinder the real scale of threats posed by using NPS. However, signals from the EU Early Warning System and other sources suggest serious concerns (Ewans-Brown, 2017, p. 37).

One of the most noticeable features and at the same time the most drastic aspect of taking new psychoactive substances is the occurrence of mass poisoning caused by "legal highs" containing synthetic cannabinoids.

In 2014, in Russia, products containing MDMB-FUBINACA were responsible for more than 600 poisonings, including 15 fatalities within 2 weeks. Only in 2014, a series of five new synthetic cannabinoids with the structure of indazole-3-carboxamide with the N-1-methoxycarbonylalkyl group were identified. The compounds have an extremely high cannabimimetic activity that have caused massive poisoning and death. The compounds have been identified by means of gas chromatography with mass spectrometry.Analytical characteristics reported for the compounds 
will allow for their identification in different materials confiscated from criminals(Shevyrin, Melkozerov, Nevero et al., 2015, pp. 6301-6315).

Over 400 suspected poisonings, including eight deaths with a possible link, were reported to the Mississippi Poison Control Center MPCC, USA in the period from 2 April to 21 April 2015 (Kasper, Ridpath, Arnold et al., 2015, pp. 1121-1122). In Poland in 2015, over 200 people were hospitalized during a few days after smoking a product called "Mocarz" ("Mighty Man").

It is difficult to disagree with the opinion of $\mathrm{K}$. Warecki, according to which the epidemic of hospitalization and a series of deaths due to the use of "legal highs" was necessary for the problem to gain due rank both in social awareness and among the priorities of entities responsible for lawmaking. Because of legal uncertainties, the actions of subsequent countries' governments were limited to prohibition of individual narcotic substances used in the production of the "boosters" (Warecki, 2010, p. 9.82).Such an example was the situation in Poland. There, media widely covered a wave of sudden poisonings after one of the amendments to the Act on Counteracting Drug Addiction (of August 2010), which delegalized,e.g. mephedrone - a stimulant similar to amphetamine, advertised by sellers as "bath salts" or "white powders", already mentioned in the article, and 9 other cannabinoids. At that time, producers quickly replaced these substances with their modifications, e.g. mephedrone was replaced with brephedrone, buphedrone or methynol, which meant that instead of mephedrone a new, dangerous, unknown substance was introduced to the market (Warecki, 2010, p. 82). And since it was not included in the list, it became legal. Paradoxically, the amendment caused the instantaneous considerable increase in the problem of "legal highs" (Tkaczyk-Rymanowska, 2016, p. 163).Then the experts agreed that the state lost the fight with the unlimited activities of chemists, for whom the bypass of legal regulations was not a problem (Warecki, 2010, p. 82).

\section{INSTITUTIONAL AND LEGAL MECHANISMS TO PREVENT THE PHENOMENON OF NEW PSYCHOACTIVE SUBSTANCES}

The response to the increase in the share of new psychoactive substances in the drug market is the new legal regulations, both national and international, 
as well as mechanisms of international cooperation within the European Union and the United Nations.

In the context of the changes on the drug market related to the emergence of new synthetic drugs (so-calleddesigner drugs), in united Europe it was decided to develop institutional and legal mechanisms for rapid introduction of certain substances under control, which would keep up with the innovation of chemists working on NPS. In response to the situation, in 1997, under the "Joint Action concerning the Early Warning System on New Synthetic Drugs", the Council of the European Union established the Early Warning System(EWS). The Central Unit of this System responsible for the implementation and development of the system became the European Monitoring Centre for Drugs and Drug Addiction (EMCDDA) based in Lisbon appointed by the European Commission to monitor the phenomenon of drug addiction in the European Union. In the first period of the EMCDDA operation, its attention was focused on new drugs being covered by legal control. In 2000, the illegal market launched tablets called "UFO" and "Mitsubishi", which are the most usual form of the notorious substance PMA - parameteroxyamphetamine, and PMMA -parameteoxymatamphetamine. Their use resulted in a series of deaths. As a result of these events, the speed of information flow became even more important. Importantly, this system allows obtaining information on user groups of new psychoactive substances (Early Warning System, 2015).

The key element for the functioning of the Early Warning System is the risk assessment. In addition, its main goals include: identification of new psychoactive substances appearing on the European drug scene, exchange of information and development of recommendations on a possible legal inspection at the European level for the Council of the European Union (hereinafter referred to as the Council). The partners in the system are the National Focal Points, so-called REITOX, located in the Member States of the EU. In Poland, this is the Information Centre on Drugs and Drug Addiction (CINN) of the National Bureau for Drug Prevention (KBPN) (Jabłoński, Malczewski, 2014, p.12-13). After detecting a new psychoactive substance, detailed information on, e.g. production and use of NPS, including more information on possible medical use, is sent by EU Member States to the 
EMCDDA in Lisbon and Europol in The Hague through the mentioned national points and the Europol national units. If the EMCDDA and Europol recognize that the information provided is important and worthy of further analysis, they present it in the form of a joint report of the EMCDDA and Europol to the Council, the EMA and the Commission.It should also be emphasized that the current monitoring of the new psychoactive substances market at a national level needs constant cooperation with the EMCDDA and other Member States of the European Union. The EMA submits to Europol and the EMCDDA some information concerning whether a new psychoactive substance has obtained the marketing authorisation, is the subject of an application for marketing authorisation, or the marketing authorisation granted to a new psychoactive substance has been suspended. Based on the joint report, the Council, acting by most of its members, may request an assessment of the health risks, social risks caused by the use, production, circulation of a new psychoactive substance, the involvement of organized crime and possible legal sanctions. In the years 2005-2017,following the provisions of the Council decision, the EMCDDA jointly drew up reports on 25 new psychoactive substances (The EU Early Warning System, European Monitoring Centre for Drugs and Drug Addiction, 2018).

In November 2017, new legal regulations which aim to strengthen the above mentioned European Early Warning System and to streamline the process of risk assessment were introduced. They result from the proposal of the European Commission which is made up of two legal acts. The first is Regulation (EU) 2017/2101 of the European Parliament and of the Council of 15 November 2017 on amending Regulation (EC) No. 1920/2006 regarding the exchange of information and new systems of psychoactive substances and the Early Warning System and procedures for risk assessment(Journal of Laws EU L 305 of 21 Nov 2017). The second act is Directive (EU) 2017/2103 of the European Parliament and of the Council of 15 November 2017 on amending the Council's Framework Decision 2004/757/JHA in order to enable new psychoactive substances to be covered by the definition of "drugs" and repealing the Council's Decision 2005/387/JHAJournal of Laws EU L 305 of 21 Nov 2017). The new legal solutions maintain the existing current threestage reaction procedure for new psychoactive substances, which consists of 
early warning, risk assessment and control activities. At the same time, these regulations significantly strengthen the existing procedures by streamlining and accelerating the data collection and evaluation processes (Strzelecka, 2017). Under the provisions of the law, the new procedure allows for the introduction of shorter deadlines for the implementation of the various stages of activities aimed at the delegalization of substances in the European Union. The EMCDDA will continue to play a leading role in monitoring the market of new psychoactive substances reported by EU Member States within the Early Warning System. Within two weeks of the EMCDDA presenting a preliminary report, the European Commission may propose a formal decision on taking control of the substance. Then, the Council of the European Union and the European Parliament will have two months to respond to the Commission's proposal. The national authorities will have 6 months from the entry into force of the decision, and not 12 as before, to take control of the substance in their country (Malczewski, 2017, p. 43).

In addition, the key role of the European Monitoring Centre for Drugs and Drug Addiction in the detection and assessment of new medicines in the European Union should be indicated based on the Council's Decision 2005/387 / JHA of 10 May 2005 on the exchange of information, risk assessment and control of new psychoactive substances. This legal instrument set up a mechanism for the rapid exchange of information on new psychoactive substances and it records information on suspected adverse reactions reported under the pharmacovigilance system.

Institutional and legal mechanisms for preventing new psychoactive substances have been developed for many years by the United Nations. In analysing the actions taken by this structure, one should pay attention to the global SMART programme (the Global Synthetics Monitoring: Analyses, Reporting and Trends). Since 2011, this programme has played a pioneering role in signalling the emergence of new psychoactive substances (Global SMART Programme, 2018).

While analysing legal regulations in individual countries, it should be noted that when undertaking actions aimed at preventing the introduction of NPS on the market, individual countries consider the UN conventions defining the control framework for production, possession, and trade in 
relation to 240 psychoactive substances. To show the scale of the problem, it should be recalled that currently the EMCDDA monitors 620 new psychoactive substances. This means that the rate of occurrence of NPS and diversity of available products have proved to be a challenge for the convention regulations as well as for the legal regulations in force in various countries.

One can show basic types of legal response at the national level. The first reaction of many European countries was the adoption of the provisions for the safety of consumers and later the extension of the scope of application or adaptation of the existing provisions in such a way as to include new psychoactive substances. In response to this phenomenon, individual countries increasingly began to create new legislation. In this respect, it is necessary to show the multiplicity of drug laws in various countries. This issue corresponds to the functioning of various definitions of offences, as well as related penalties. The creators of the latest European Drugs Report underline that in the recently adopted legislation on new drugs, one can see the general trend characterizing national drug legal regulations, i.e. lowering the penalty for possession of drugs for personal use. It should be noted that most new regulations concerning strictly new psychoactive substances provide for legal sanctions only for the trade in illegal substances, but not for possession for own use (Report, 2017, pp. 36-37).

The creators of the report on the drug market in Europe emphasize that for the operational and strategic purposes, it is necessary to analyse systematicallybusiness models functioning on the drug market. It is becoming increasingly important to understand the relationship and potential interactions between different areas of the drug market, as well as functioning, roles, and organizational models. Considering these dependencies will ensure greater effectiveness of the process of counteracting illegal activity on the drug market. For this purpose, it is necessary to show adequately the modus operandi, structural weaknesses and threats emerging in connection with criminal activities (The EU Drug Markets Report. Strategic Overview, 2016, p. 11). It should also be emphasized that in detection and prevention of the emergence of NPS, the identification of recipients' groups seems to be extremely important. The legal and institutional mechanisms, including in particular the Early Warning System, are making it increasingly possible. 


\section{SUMMARY AND FINAL CONCLUSIONS}

In summary, it should be noted that the issue of new psychoactive substances presented in this article is multidisciplinary and multiplanar. Particular attention should be paid to the development of appropriate legal mechanisms in the area of NPS control. The examples of loopholes presented in the article based on national and international legal regulations undoubtedly determined the rapidly growing NPS market. Legal regulations penalizing the circulation of new psychoactive substances created a comfortable situation for producers and traders who took advantage of the fact that until a given substance is found in the list of illegal substances it remains legal. At present, one can see an intensified system of creating new or amending existing legislative regulations. The mechanisms functioning in the European Union in the field of the Early Warning System as well as legal regulations in individual countries have been improved. An example is the modification of the existing provisions of the Polish Act on Counteracting Drug Addiction (the consolidated text, Journal of Laws of 2018, item1030) and on the State Sanitary Inspection (the consolidated text, Journal of Laws of 2017, item 1261).These laws were amended by the Act of 20 July2018 on the amendment to the Act on Counteracting Drug Addiction and the Act on the State Sanitary Inspection (Journal of Laws of 2018, item 1490). The main purpose of the amendment was to penalize all acts related to the possession, production, distribution of "boosters" and to create legal instruments to enforce them. The introduced provisions are aimed at enabling a more effective fight against new psychoactive substances.

The issue of illegal trade in new drugs has become a problem of law enforcement in many countries in recent years. Even more so, as regards the activities aimed at combating the market for new drugs, the importance and substance of cooperation between Member States within Europol should be emphasized.

The theses put forward in the introduction to this article seem to be justified in the author's opinion. The lack of appropriate regulations has led to a wide range of NPS. On the example of the information presented in this study, one can also point to the laboratory synthesis of psychoactive substances as another factor serving the dissemination of NPS. The two issues 
mentioned above, i.e. the lack of proper legal regulations in this regard and the thriving laboratories producing new drugs, correspond with each other in a strict manner. Because of their coupling, a situation arose in which attempts to react properly to new psychoactive substances, mainly to identify them, did not meet the advanced and innovative market of new drugs to a significant extent.

In the light of the information presented in this article, one should also recognize the high criminogenic capacity of the new psychoactive substances phenomenon, which closely correspond to the subject of addiction, which has always been a manifestation of the social life pathology. The criminogenic nature of "new drugs" is confirmed by the fact that the large group of NPS recipients are convicted persons. In addition, it should be emphasized that for many groups of people taking NPS, their use has formed a continuum of previous experiences with substances covered by legal control. It is also worth pointing out that structurally (with some exceptions) the mechanism of production and in some sense of distribution (creation of the market) of NPS resembles the drug market.

\section{References}

Abdulrahim, D., Bowden-Jones, O. (2015).Guidance on the management of acute and chronic harms of club drugs and novel psychoactive substances, Novel Psychoactive Treatment UK Netwotk, London.

Deluca, P., Davey, Z., Corazza, O., Di Furia, L., Farre, M., Flesland, L.H. (2012). Identifying emerging trends in recreational drug use; outcomes from the psychonaut web mapping project, Progress in Neuro-Psychophamacolgy\& Biological Psychiatry39(2), DOI:10.1016/j.pnpbp.2012.07.011.

European Drugs Report. Trends and Developments (2017), European Monitoring Centre for Drugs and Drug Addiction, Luxembourg. ISBN 9497073978922.

Ewans-Brown, M., Sedevor, R. (2017).New Psychoactive Substances: Driving Greater Complexity into the Drug Problem,Addiction, V. 112, Issue, January, DOI:10.1111/ add.13528.

Farre, M., Galindo, L., Torrens, M. (2014). Addiction to Hallucinogens Dissociatives, DesignerDrugs and "LegalHighs", in: Textbook of Addiction Treatment: International perspectives, N. El-Guebaly, G. Carra, M. Galanter. ISBN 9788847053212. 
Halford, B. A glimpse inside the sophisticated world of synthetic cannabinoids. Chem

Eng News. Available at: http://cen.acs.org/articles/93/web/2015/04/GlimpseInside-So- phisticated-World-Synthetic.html, access: 20.04.2017.

Hanausek, T. (2009).Kryminalistyka [Criminology], Krakow, Wydawnictwo Zakamycze. ISBN 8374440880.

Jabłoński, P., Malczewski, A. (2014).Dopalacze. Skala zjawiska i przeciwdziałanie [Legal Highs. Scale of the Phenomenon and Counteracting],Warszawa, National Bureau for Drug Prevention. ISBN 9788393807185.

Jędrzejko, M., Kowalewska, A. (2009).Narkomania - wybrane pojęcia i definicje [Drug Addiction - Selected Terms and Definitions], ed. T Jędrzejko, Narkomania - spojrzenie wielowymiarowe [Drug Addiction - Multidimensional View], PułtuskWarsaw, Oficyna Wydawnicza ASPRA-JR.ISBN 9788375451214.

Kasper, A.M., Ridpath, A.D, Arnold, J.K., Chatham-Stephens, K., Morrison, M., Olayinka, O., Parker, C., Galli, R., Cox, R., Preacely, N., Anderson, J., Kyle, P.B., Gerona, R., Martin, C., Schier, J., Wolkin, A., Dobbs, T. (2015). Severe Illness Associated with Reported Use of Synthetic Cannabinoids - Mississippi, April 2015, MMWR Mordibity and Mortality Weekly Report., Oct 9;64(39), DOI:10.15585/ mmwr.mm6439a7.

Lindigkeit, R., Boeheme, A., Eiserloh, I., Luebbecke, M., Wiggermann, M., Ernst, L., Beuerle, T. (2009).Spice: never ending story?, Forensic Science International, V. 191, Issues 1-3, 30 October, DOI:10.1016/j.forsciint.2009.06.008.

Malczewski, A. (2017).Nowe substancje psychoaktywne - coraz groźniejsze [New Psychoactive Substances - More and More Threatening], Serwis Informacyjny Uzależnienia, issue 4(80). ISSN 2543-8816.

Michalewki, B., Granowski, K., Wodowski, G. (2015).Nowe Substancje Psychoaktywne. Zdrowie-Prawo-Zagrożenia [New Psychoactive Substances. Health-Law-Threats, Krakow, Stowarzyszenie Monar.

Morris, H., Criminal chlorination. An interview with a clandestine chemist, Available at: http://www.vice.com/read/criminal-chlorination-0000350-v19n9, access: 17.04.2017.

Rymanowska-Tkaczyk, K. (2016).Kilka uwag na temat środka zastępczego w aspekcie teoretycznoprawnym [A Few Comments on the Substitute Means in the Theoretical Legal Aspect], "Palestra 2016", item 23/a, Http://www.e.palestra.pl, access: 20.08.2018. ISSN 0031-0344.

Shevyrin, V., Melkozerov, V., Nevero, A., Eltsov, O., Shafran, Y., Morzherin, Y., Lebedev, A.T. (2015).Identification and analytical characteristics of synthetic cannabinoids with an indazole-3-carboxamide structure bearing a N-1-methoxycarbonylalkyl 
group, Analytical and Bioanalytical Chemistry, August, Volume 407, Issue 21, DOI 10.1007/s00216-015-8612-7.

The Challenge of New Psychoactive Substances - Global SMART Programme(2013),United Nations Office on Drugs and Crime (UNODC), Vienna, United Nations Publications.

The EU Drug Markets Report. Strategic Review 2016, European Monitoring Centre for Drugs and Drug Addiction, Joint publications of the EMCDDA and Europol, Publications Office of the European Union, Luxembourg. ISBN 9789294970411.

Tkaczyk-Rymanowska, K., (2016).Problem tzw. dopalaczy i nowych narkotyków $w$ świetle zmian normatywnych do ustawy o przeciwdziałaniu narkomanii [The Problem of So-Called Legal Highs and New Drugs in the Light of Normative Changes to the Law on Counteracting Drug Addiction] "Prokuratura i Prawo" 9. ISSN 1233-2577.

Warecki, K. (2010).Dopalacze [Legal Highs], Radom, Polskie Wydawnictwo Encyklopedyczne. ISBN 9788375570960.

World Drug Report (2013). United Nations Office on Drugs and Crime, New York, United Nations Publications. ISBN 978-92-1-148273-7.

Woronowicz, B.T. (2003).Bez tajemnic: o uzależnieniach i ich leczeniu [No Secrets: about Addictions and Their Treatment], Warszawa, Institute Instytut Psychiatrii i Neurologii. ISBN 8385705554.

Zajączkowski, K. (2003).Uzależnienia od substancji psychoaktywnych [Addiction to Psychoactive Substances], Warszawa, Wydawnictwa Szkolne i Pedagogiczne. ISBN 8302089338 .

\section{Online sources}

Global SMART Programme, UNODC Early Warning Advisory on New Psychoactive Substances, www.unodc.orga, access: 29.08.2018.

Nowesubstancjepsychoaktywne(dopalacze)-chemicykontraprawnicy [New Psychoactive Substances (Boosters) - Chemists versus Lawyers], www.uslugikryminalityczne.pl, access: 25.08.2018.

Nowe substancje psychoaktywne tzw. dopalacze [New Psychoactive Substances, SoCalled Legal Highs] (2017), Narodowy Instytut Leków, Narodowe Laboratorium Kontroli Produktów Leczniczych Wyrobów Medycznych i Produktów Biobójczych, Http://www.nil.gov.pl, access: 28.08.2018.

Strzelecka A., Nowerozwiązaniaprawne dotyczace Nowych Substancji Psychoaktywnych [New Legal Solutions for New Psychoactive Substances] (2017), Centrum Informacji o Narkotykach i Narkomani Krajowego Biura ds. Przeciwdziałania Narkomanii, access: 22.08.2018. 
System Wczesnego Ostrzegania [Early Warning System] (2015), Information Centre for Drugs and Drug Addiction National Office for Combating Drug Addiction, www.cinn.gov.pl, access: 27.08.2018.

The EU Early Warning System (2018), European Monitoring Centre for Drugs and Drug Addiction, www.emcdda.europa.eu, 2018, access: 27.08.2018.

\section{Legal acts}

Act of 14 March 1985 on the State Sanitary Inspection (the consolidated text, Journal of Laws of 2017, item 1261).

Act of 20 July 2018 on the amendment to the Act on Counteracting Drug Addiction and the Act on the State Sanitary Inspection (Journal of Laws of 2018, item 1490).

Act of 29 July 2005 on Counteracting Drug Addiction (the consolidated text, Journal of Laws of 2018, item1030).

Directive (EU) 2017/2103 of the European Parliament and of the Council of 15 November 2017 on amending the Council's Framework Decision 2004/757/ JHA in order to enable new psychoactive substances to be covered by the definition of "drugs" and repealing the Council's Decision 2005/387/JHA Journal of Laws EU L 305 of 21 Nov 2017).

Protocol amending the Uniform Convention on Narcotic Drugs of 1961 drawn up in Geneva on 25 March 1972, Journal of Laws of 1996, No 35, item 149.

Regulation (EU) 2017/2101 of the European Parliament and of the Council of 15 November 2017 on amending Regulation (EC) No. 1920/2006 regarding the exchange of information and new systems of psychoactive substances and the Early Warning System and procedures for risk assessment Journal of Laws EU L 305 of 21 Nov 2017).

UN Convention on Psychotropic Substances drawn up in Vienna on 21 February 1971, Journal of Laws of 1976, No 31, item 180.

Uniform UN Convention on Narcotic Drugs of 1961, drawn up in New York on 30 March 1961. Journal of Laws of 1966, no. 45, item 277, as amended. 